\title{
Friendship Relationships between Turkish-French Children and Their French Peers ${ }^{1,2}$
}

\author{
Yasemin Güleç3
}

\begin{abstract}
This study aimed to examine the relationships between Muslim-Turkish children born in France and their French peers. 96 students aged 9-15 participated in the study. 60 of the students were girls, and 36 were boys. The drawings, interviews about the drawings and answers given to the open-ended questions were evaluated together. The data were analysed by the maxqda 2018 software. The study was designed with the research method of phenomenology and analysed by the induction method. The data were depicted in two main themes as tolerant and discriminatory relationships. Differences in terms of gender and age in these themes were examined. Girls made more friends with their French peers. The friendships with the peers increased from 9 years old to 10-12. However, this rate decreased at 13-15 years. Boys expressed that they were exposed to discriminatory attitudes and behaviours by their native friends more. There was an increase from 9 to 10-12 in perceived racial/ethnic exclusion. This decreased at 13-15 years of age. There was a continuous increase in perceived religious exclusion with increasing age.
\end{abstract}

Keywords: Immigration children, host children, friendship relationships, tolerance, discrimination.

\footnotetext{
${ }^{1}$ This article was verbally presented at the Conference on Multiple Religious Identities /16th Annual Conference of the European Association for the Study of Religions (EASR) held on June 17-21 in 2018 in Switzerland/Bern.

${ }^{2}$ This research titled "Friendship Relationships between Turkish-French Children and Their French Peers" was approved by Hacı Bektaş Veli University Ethics Committee with the number 08 meeting dated 12.03.2020.

${ }^{3}$ Assist.Prof.Dr. Nevşehir Hacı Bektaş Veli University, Faculty of Theology, Department of Philosophy and Religious Sciences, yasemingulec@nevsehir.edu.tr, https://orcid.org/0000-0001-8843-3270.

Received: 16.08.2019, Accepted: 29.04.2020.
} 


\title{
Türk-Fransız Çocuklar ve Fransız Akranları Arasındaki Arkadaşııı İliş̧ileri
}

\begin{abstract}
$\ddot{O} z$
Bu çalışmada Fransa'da doğan Müslüman-Türk çocukları ile Fransız akranları arasındaki ilişkiler incelenmiştir. Çalışmaya 9-15 yaş arasında 96 öğrenci katılmıştır. Öğrencilerin 60'ı kız, 36'sı erkektir. Öğrencilerin çizimleri, çizimlerle ilgili görüşmeler ve açık uçlu sorulara verilen yanıtlar birlikte değerlendirilmiştir. Veriler MAXQDA 2018 yazılımı ile analiz edilmiştir. Çalışma, nitel araştırma yöntemlerinden fenomenolojik araştırma yöntemi ile desenlenmiş ve tümevarım yöntemi ile analiz edilmiştir. Veriler, hoşgörülü ve ayrımcı ilişkiler olarak iki ana temada tasvir edilmiştir. Bu temalarda cinsiyet ve yaş açısından farklılıklar incelenmiştir. Çalışmanın bulgularına göre, kız çocukların Fransız akranlarını daha çok arkadaş edindikleri görülmüştür. Akranlarıyla olan dostluklar 9 yaşından 10-12 yaş aralığına doğru yükseldiği görülmüştür. Ancak bu oran 13-15 yaşlarında azalmıştır. Erkek çocuklar, kız çocuklara nazaran, Fransız akranları tarafindan ayrımcı tutum ve davranışlara daha çok maruz kaldıklarını ifade etmişlerdir. Algılanan ırksal / etnik dışlanmada 9 yaşından 10-12 yaş aralığına doğru bir artış olmuş; bu artış 13-15 yaş aralığında azalmıştır. Artan yaşla birlikte algılanan dini dışlanmada sürekli bir artış olmuştur.
\end{abstract}

Anahtar Kelimeler: Gö̧̧men çocuklar, yerli çocuklar, arkadaşlık ilişkileri, hoşgörü, ayrımcıllk 


\section{Introduction}

In formerly ethnically homogeneous Western European countries, the combination of a host majority and various immigrant minorities nowadays raised some difficulties for the natives and immigrants (McLaren, 2003). Children born in a country where their parents migrate face maintaining their religion and culture and protecting their identity and adaptation to the country's national identity and the host culture (LaFromboise, Coleman, \& Gerton, 1993; Szapocznik \& Kurtines, 1993; Verkuyten \& Martinovic, 2012). This facing may result in different processes, such as losing their religious and ethnic identities altogether, with less emphasis on their identity, to a stronger commitment to national identity or to combining their identity and national identity in a healthy way.

Even though there are differences depending on location, second-generation Muslim immigrants usually gradually adapt to the country (Alba, 1999; Portes \& Zhou, 1993), tend to attach less importance to their religious and ethnic identity and have a stronger sense of belonging (Maliepaard, Lubbers, \& Gijsberts, 2010). In some cases, this situation may lead children to move away from their own culture and have some conflicts with their families.

The degree of tolerant or discriminatory relationships between immigrant and native children may differ based on social, historical and religious relations. Ethnic and racial majority and minority children may experience prejudice and exclusion in their relationships. However, minority children experience it more (Rosenbloom \& Way, 2004). Even though the degree and effect of this perception may vary from child to child, it may still be stated that immigrant children have more difficulty in living in the host country, both psychologically and socially.

Most studies investigated the attitudes of natives towards immigrants and ethnic minorities. These studies often focused on the majority's attitude towards reducing prejudice and discrimination against minorities (Aboud, 1993; Bigler \& Liben, 1993; Killen, 2007). After the first study on minority children (Clark \& Clark, 1950), other studies were conducted with racial minority children (Bigler \& Liben, 2007; Flanagan, Syvertsen, Gill, Gallay, \& Cumsille, 2009) and ethnic minority immigrants (Alba, 2005; Leszczensky \& Pink, 2016; Leszczensky, Stark, Flache, \& Munniksma, 2016; Munniksma, Verkuyten, Flache, Stark, \& Veenstra, 2015; 
Sabatier, 2008; Stevens, Pels, Vollebergh, \& Crijnen, 2004; Verkuyten, Thijs, \& Stevens, 2012) in the last two decades.

There is more research focused on the perceptions of native children towards immigrants and ethnic minorities in comparison to research focused on the perceptions of immigrants on native children and friendship relationships. This study examines the perceptions of immigrants about natives and their friendship relationships with them. It uses children's drawings as a diagnostic method. To the best of our knowledge, no study has investigated the friendship relationships of Muslim-Turkish children living in Strasbourg and their native peers through drawings and semistructured interviews. The focus of this study is to investigate forms of friendship relationships and whether these relationships vary by gender and age. The methodology of this study will contribute to the literature.

\section{Tolerant Friendship Relationships between Immigrant and Native Children}

Acculturation is a complex process that immigrants experience when they encounter new cultural values. As most exposure to a new culture occurs at school and in peer interactions (Shih, 1998), peer interactions may affect acculturation of migrant children and adolescents, and likewise, the level of acculturation may affect friendship models (Ting-Toomey, 1981). There are four general implications of acculturation on how immigrants identify as a sub-group of the larger society: Children who assimilate to the host culture and often identify with mainstream friends, those who associate themselves with friends from their own culture or ethnicity, those who successfully integrate the two cultures with their friends from two cultures, and those who are marginalised or alienated to both cultures (Berry, Kim, Power, Young, \& Bujaki, 1989; Phinney, 1990).

Positive friendships between minority and native children play an important role in minority students' feelings of being a part of the host society (Reitz, Asendorpf, \& Motti-Stefanidi, 2015) and understanding the majority (Feddes, Noack, \& Rutland, 2009; Jugert, Noack, \& Rutland, 2011; Kawabata \& Crick, 2008; Munniksma et al., 2015). Positive friendships -ignoring the group norms of children (identity, beliefs, norms and social status of a group)- are often possible through moral reasoning, concerns for the welfare of others, justice and empathy (Hitti, Mulvey, \& Killen, 2017; Malti, Killen, \& Gasser, 2011). 
In some cross-sectional studies, immigrants who felt more connected to the country showed less intra-group bias (Nier et al., 2001; Pfeifer et al., 2007). Native children may notice immigrants who are closer to the host society's culture and have similar values to themselves, and they may include these immigrants more easily and evaluate them more positively (Schaafsma, Nezlek, Krejtz, \& Safron, 2010; Van Oudenhoven, Prins, \& Buunk, 1998; Verkuyten \& Thijs, 2010; Verkuyten, Thijs, \& Sierksma, 2014; Zagefka, Tip, González, Brown, \& Cinnirella, 2012).

A longitudinal survey of ethnic minority adolescents in the Netherlands (12-13 years) indicated that friendship with majority peers was related to stronger identification with the host society. Ingroup friendships or ingroup identification was unrelated to outgroup attitudes. The relationship between host society identification and majority friendships was bidirectional (Munniksma et al., 2015)

A cross-sectional study (Leszczensky et al., 2016) found no bidirectional relationship between national identity and native friendships. Native students preferred to befriend immigrants who had a strong national identity. However, neither did immigrants prefer to be similar to the national identification of their friends, nor did having many native friends increase their national identification.

\section{Discriminatory Friendship Relationships between Immigrant and Native Children}

Similarities in group norms are a key predictor of friendship choices (S. Smith, Maas, \& van Tubergen, 2014; Stark, Flache, \& Veenstra, 2013). This may be because interaction with similar people based on a mutual understanding is easier and more rewarding (Leszczensky \& Pink, 2015; A. Smith \& Schneider, 2000).

In multicultural societies, the coexistence of the majority and various immigrant minorities may highlight differences in group norms and create conflicts (Alba, 2005) where distinctions pile up. Minority children may be exposed to exclusion because of their ethnic origin, race and religion. This may occur through inequitable distribution of resources and in intergroup peer contexts. Social discrimination and exclusion may affect children's perceptions and judgments about peer relationships (Sabatier, 2008). 
Discrimination is one of the biggest challenges faced by migrant youth (Wong, Eccles, \& Sameroff, 2003). In developmental identity models (Phinney, 1989), perceived discrimination is considered an event that creates awareness among groups and ethnic origins. Perception of discrimination may strengthen the definition of ethnic groups and weaken their ties with the national group (Bourhis, Moise, Perreault, \& Senecal, 1997). There is also evidence that perception as a target of ethnic discrimination causes negative consequences in adaptation of immigrant youth, including low academic success (Wong et al., 2003)

A study examining the link between peer preferences of immigrant adolescents and personal ethnic discrimination revealed that personal ethnic discrimination was a result, but a low number of peers was not preferential. If youths experience quality friendships on a bilateral level, they may look beyond the perceptions of discrimination on the macro level (Reitz et al., 2015). Even if there are differences among children, the perception of discrimination may continue to have devastating effects for adolescents' experiences of individual ethnic discrimination (Pascoe \& Smart Richman, 2009).

Children who experience exclusion may be at risk for demonstrating prejudicial behaviour toward others and perpetuating a cycle of negative intergroup attitudes (Nesdale \& Brown, 2004). Decisions on inclusion or exclusion of ethnic external group members emphasise tensions between moral decisions and other factors such as cultural norms, traditions, personal factors and privileges (Hitti et al., 2017).

Minority children's exclusion experiences may differ. While a Latin American child is subject to prejudice and exclusion based on race and ethnic origin, Arab Americans may be subject to discrimination based on religion, language and personal characteristics (Flanagan et al., 2009). Turkish children in the Netherlands were reported to experience greater perception of exclusion than Moroccan and Syrian children (Verkuyten \& Kinket, 2000; Verkuyten \& Thijs, 2002).

\section{Racial and Ethnic Categorisation and Friendship Choices}

Many studies have shown ethnic awareness in children (conscious recognition of race or ethnicity in individuals and groups, and the ability to label them correctly) increases with age, and this may be noticed between 3 and 5 years (Clark \& Clark, 1950; Patterson \& Bigler, 2006; 
Ramsey, 1991; Ramsey \& Myers, 1990). 7-8-year-old children can clearly categorise their national identities and prefer their own country (Murphy \& Laugharne, 2013). After 7-8 years of age, children recognise that minority ethnic groups are associated with different stereotypes and there are differences in relative status among minorities (Davis, Leman, \& Barrett, 2007; Lam \& Leman, 2003).

As children grow up, information about group normativity becomes increasingly important in assessing others. However, it remains unclear how far ethnic group normativity influences children's friendship choices (Leman et al., 2013). Children have higher tendency to play and interact with the same ethnic group from preschool (Finkelstein \& Haskins, 1983; Fishbein \& Imai, 1993) to childhood (Boulton, 1996; Davey \& Mullin, 1982; Leman \& Lam, 2008; Leman et al., 2011). Peer relationships provide an important social context for adolescent development (Brechwald \& Prinstein, 2011; Meeus, 2011). Intra-ethnic friendships show more intensity during adolescence (Kao \& Joyner, 2004), and cross-friendships are seen as an exception (Aboud, Mendelson, \& Purdy, 2003). It was also found that inter-ethnic friendships predict more positive group behaviours in middle childhood and adolescence (Vervoort, Scholte, \& Scheepers, 2011).

Majority children in different cultures preferred the members of their own ethnic group more (Enesco, Navarro, Paradela, \& Guerrero, 2005; Griffiths \& Nesdale, 2006; Kowalski, 2003; Nesdale, Maass, Griffiths, \& Durkin, 2003). However, minority children mostly paid more importance to social justice, empathy and fairness in friendships (Hitti et al., 2017). Minority children showed less intra-group bias compared to majority children (Griffiths \& Nesdale, 2006; Leman \& Lam, 2008; Vaughan, 1978; Verkuyten, 2007). In a study conducted with the 13-15 and 16-18 age groups, ethnic identity increased with age and predicted positive in-group attitudes- while these attitudes contributed to positive out-group attitudes (Phinney, Ferguson, $\&$ Tate, 1997).

Studies investigating the social networks of young immigrants and natives in countries showed that intra-group preferences play important roles in formation of friendship ties (Hallinan \& Teixeira, 1987; Vermeij, van Duijn, \& Baerveldt, 2009). Immigrant children from the preschool period (Leman et al., 2013) to childhood (Verkuyten \& Kinket, 2000) and from adolescence to youth (Brüß, 2005; Phinney et al., 1997) tended to show stronger preferences for co-ethnic 
peers than for interethnic friends. However, this ingroup bias might be less pronounced if migrants strongly identify with the host country (Nier et al., 2001; Pfeifer et al., 2007).

\section{Religious Categorisation and Friendship Choices}

Although religious groups are of great importance for supporting the development of both individual and group identity (Seul, 1999), studies on religious group categorisation and intergroup attitudes and friendships are far fewer than those on race and ethnic groups (Van der Straten Waillet \& Roskam, 2012b).

Van der Straten Waillet and Roskam suggested that young children do not seem to be able to understand that their social environment could be categorised based on religious beliefs. This understanding is only reached in the middle of childhood at about 8 or 9 years of age, and while the vast majority of children growing up in a heterogeneous environment are likely to be aware of religious differences at 9 years of age, some children from religiously homogeneous environments do not acquire this until 11 years of age. Children younger than 9 may know about some religious labels, but their understanding of these is likely to be inaccurate probably because of their cognitive limitations. Most young children think religious groups, like social groups, are based on physical or behavioural qualities, rather than the shared belief of group members (Van der Straten Waillet \& Roskam, 2012a). While religious discrimination is often seen in childhood, it decreases in pre-adolescence and adolescence (Van der Straten Waillet \& Roskam, 2012b).

While ethnic homophily is a factor in the friendship ties of children, religious homophily may worsen the problem of ethnic segregation. This is especially true if large groups of immigrants come from countries where the dominant religion is different (Windzio \& Wingens, 2014). Intergroup studies (Leszczensky \& Pink, 2016; Verkuyten \& Thijs, 2010) on how religion and religiosity affect child and youth friendship choices in Western Europe are fewer than in-group studies (S. Smith et al., 2014; Windzio \& Wingens, 2014) that examined whether youths prefer having friends of the same religion. Religion might affect not only adolescents' preferences on whom to befriend but also whom not to befriend.

Understanding how religious diversity affects inter-group friendship preferences is particularly important in adolescence. Religious identities are quite stable in adolescence (Lopez, Huynh, 
\& Fuligni, 2011). Early adolescents derive the most meaning from their religious group affiliations. Dutch early adolescents perceived Muslims as a threat and had a prejudiced perception against them (Velasco González, Verkuyten, Weesie, \& Poppe, 2008; Verkuyten \& Thijs, 2010). Christian and non-religious youth may be reluctant to be friends with their Muslim peers compared to peers from other religious groups (Windzio \& Wingens, 2014). The reason may be anti-Muslim attitudes and prejudices in Europe (Foner \& Alba, 2008; Strabac \& Listhaug, 2008).

In a study focused on adolescents' friendship networks, how religion and religiosity affect intergroup and intra-group friendship choices, while Muslim youth preferred to be friend Muslim peers, Christian youth displayed no evidence of religious homophily. For Muslims, higher levels of religiosity increased this preference further. Regardless of their individual religiosity regarding inter-group friendships, Muslim youth were socially separated from their non-Muslim peers because of the reluctance of Christian and non-religious youth to befriend their Muslim peers (Leszczensky \& Pink, 2016).

The aim of this study was to determine the perceptions and friendship relationships of secondgeneration Muslim-Turkish children born in Strasbourg about their native French peers. Research on the friendship relationships between immigrants and native children generally focused on adolescents and young people. This study examined the developmental and sociocognitive relationships between immigrant children and native children from middle childhood to middle adolescence (9-15 years). The attempts of identifying friendship models between racial/ethnic and religious groups and efforts of understanding the causes of discriminatory behaviours in peer relationships could contribute significantly to developmental research in middle childhood and adolescence. Racial/ethnic and religious diversity experience in middle childhood could have a sustained impact on attitudes in youth and adulthood.

This study focused on peer relationships at school, an important context for socialisation, using children's drawings, which are one of the best tools projecting the unconscious levels of the inner group of the individual more than verbal forms of expression (Abraham, 1990). Many other intercultural studies - although they used larger samples - generally used quantitative methods. 
According to Muslim-Turkish children, friendship relationships in the context of school are mostly based on respect and love rather than discrimination and exclusion based on stereotypes and prejudices. In this study, the Muslim-Turkish children stated that they were exposed to racial/ethnic (being Turkish) and religious (being Muslim) discrimination and exclusion.

\section{Method}

\section{Participants and procedure}

The study was conducted with second-generation Muslim-Turkish children born in Strasbourg/France. They were studying Islamic religion on the weekends (two days a week) at the Strasbourg Yunus Emre Mosque. 96 students aged 9-15 years were included. 60 of the students were girls, and 36 were boys. Firstly, the students were seated in rows one by one to prevent them from being influenced by each other. A4 paper, 12-colored crayon boxes, pencils and erasers were distributed to each participant. Afterwards, the students were asked to draw a picture expressing friendship relationships with their French peers. Drawing time was not limited so that the children could draw freely. This time varied between 15 and 30 minutes. Afterwards, each child was interviewed individually about the drawings. This time ranged from 4 to 5 minutes. Afterward, semi-structured interviews were held about their drawings to understand their feelings, thoughts, and behaviors. Each student was asked three open-ended questions: i. Are you happy/unhappy with living together with different peer groups in the school context? Could you explain the reason for this? ii. Who are your best friends at school? iii. Are you or are you not exposed to discrimination and exclusion by your French peers? Could you explain the reason for this? The open-ended question time ranged from 7 to 9 minutes. In this study, 25-30 minutes were spent on average for each student.

In this study, the drawings, interviews about the drawings and answers given to the open-ended questions were evaluated together. The data were analysed with the maxqda 2018 software. This is a phenomenological study whose results were analysed by the induction method, which is a systematic content analysis method. In the phenomenology research design, data analysis is aimed at revealing experiences and meanings. Inductive content analysis aims to reveal the underlying concepts of data and the relationships between these concepts by coding (Strauss \& Corbin, 1990). Inductive analysis steps may be listed as encoding data, defining themes, organising and defining themes according to codes and interpreting the findings (Y1ldirım \& 
Şimşek, 2016). Initially, the data obtained from the students' drawings and interviews were coded, and themes were created by combining the relevant codes.

After this step, the data were reviewed 4 times to confirm the relationships of concepts to codes and the relationships of codes to themes. In this study, different data collection tools were used together as pictures, interviews and open-ended questions to strengthen the validity. The data were independently coded by two researchers, and the codes and themes that emerged were compared. The analyses were carried out by two different researchers who are experts in qualitative analysis in MAXQDA for the reliability of the study. Additionally, the qualitative categories that were obtained were digitised. Digitisation increases the reliability of qualitative research. This research titled "Friendship Relationships between Turkish-French Children and Their French Peers" was approved by Hacı Bektaş Veli University Ethics Committee with the number 08 meeting dated 12.03.2020.

The data were depicted in two main themes as tolerant and discriminatory relationships. Tolerant relationships were divided into four main codes: "Living together as a family", "there is no discrimination", "best friendships between groups", "Turkish-French peer relationships (minority-majority peer relationships as tolerant relationships)." Discriminatory relationships were divided into two main codes: "Turkish-French peer relationships (minority-majority peer relationships as discriminatory relationships)", "exclusion by some French teachers". After this, the main codes and sub-codes were analysed considering gender and age.

\section{Results}

While the main aim of this study was to determine the friendship relationships of MuslimTurkish children with their French peers, the students did not limit their peer relationships to their French peers in their drawings. The pictures also included relationships with other minority groups living in Strasbourg. As a result of coding, the main themes, codes and subcodes were as given in the tables in the following sections.

\section{Tolerant relationships}

Tolerant Relationships included four codes as "Living together as a Family", "There is no Discrimination", "Best Friendships between Groups", "Turkish-French Peer Relationships". 
The code "Best Friendships between Groups" consisted of four sub-codes. The code "TurkishFrench Peer Relationships" consisted of three sub-codes (Figure 1).

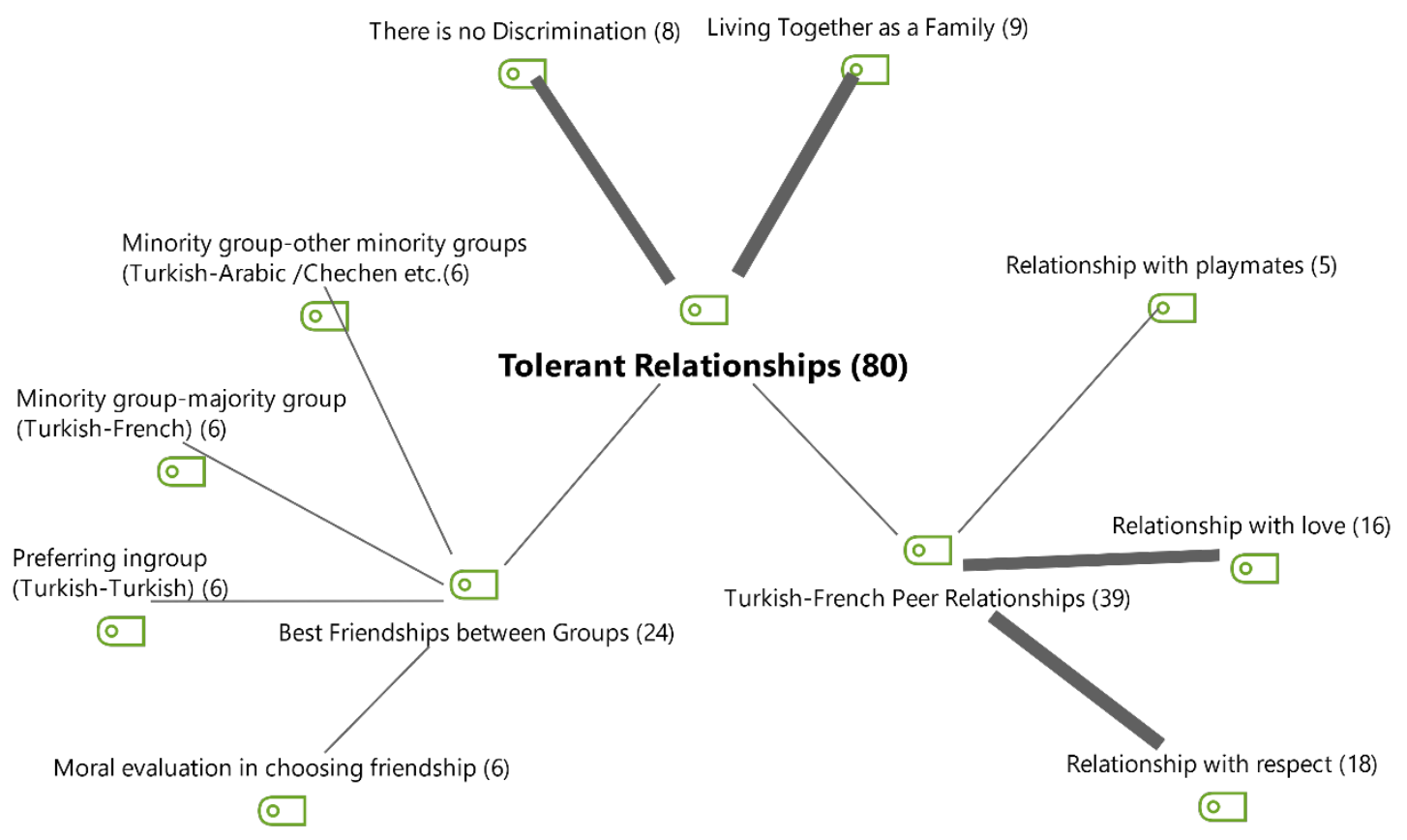

Figure 1. Tolerant relationships code theory model

$33 \%$ of the boys and $68 \%$ of the girls thought they lived together with their peers in Strasbourg as families of different races, ethnicities and religions (Table 1). Similarly, respectively $38 \%$ and $63 \%$ of the respondents said no one was subjected to racial, religious or other social discriminatory attitudes and behaviours. In both episodes, the girls thought they had more relationships of tolerance in friendship than the boys. Some students in the paintings and interviews stated who their best friends were. The boys' best friends were mostly students in the majority group, French children. The girls preferred the majority group less in friendship. The boys and girls chose their best friends from other minority groups at the same proportion. The girls preferred own group in best friendships. Likewise, in choosing their best friends, only girls attached importance to their friends' moral attitudes and behaviour. Turkish-Muslim students in relationships with their French peers were communicating with respect, being playmates and love. The girls paid more importance to love and respect in their communication with the majority group. The boys preferred mostly playmate friendship with more superficial communication. 
Table 1

Tolerant Relationships by Gender

\begin{tabular}{llll}
\hline Tolerant Relationships & Boy & Girl & Total \\
\hline Living together as a family & 33,33 & 66,67 & 100,00 \\
There is no discrimination & 37,50 & 62,50 & 100,00 \\
Best Friendships Between Groups & & & \\
$\quad$ Minority group-majority group (Turkish-French) & 33,33 & 66,67 & 100,00 \\
$\quad$ Minority group-other minority groups (Turkish-Arabic /Chechen et & 50,00 & 50,00 & 100,00 \\
$\quad$ Preferring own ingroup (Turkish-Turkish) & 0,00 & 100,00 & 100,00 \\
$\quad$ Moral evaluation in choosing friendship & 0,00 & 100,00 & 100,00 \\
Turkish-French Peer Relations & & & \\
$\quad$ Relationship with respect & 38,89 & 61,11 & 100,00 \\
$\quad$ Relationship with playmate & 60,00 & 40,00 & 100,00 \\
$\quad$ Relationship with love & 25,00 & 75,00 & 100,00 \\
\hline SUM & 31,25 & 68,75 & 100,00 \\
\hline N (Documents) & $(36)$ & $(60)$ & $(96)$ \\
& $\% 37,5$ & $\% 62,5$ & $\% 100$ \\
\hline
\end{tabular}

As shown in Table 2, the 9-year-olds had no idea about "Living together as a family". 67\% of the $10-12$-year-olds and $33 \%$ of the 13-15-year-olds thought all groups lived together as a family in Strasbourg. Similarly, the 9-year-olds did not express an opinion on "There is no discrimination". $50 \%$ of the 10-12-year-olds and 13-15-year-olds said there was no discrimination. In selecting the best friends, the 9-year-olds firstly made friends with the majority, secondly preferred their in-group, and other minorities the least. The 10-12-year-olds firstly made friends with other minority groups, secondly preferred their in-group, and the majority at the least. The 13-15-year-olds did not express an idea about choosing their best friend. Moreover, the 9-year-olds old said they firstly had respect-related relationships and secondly had love-related relations. The 10-12-year-olds were the age group that had the most contact with their French peers on every level as respect, playmates and love. The 13-15-yearolds also had relationships on every level, but there were less frequent contacts than the 10-12year-olds. Only the 10-12-year-olds chose their best friends according to their moral attitudes and behaviours rather group norms. In this regard, the 9-year-olds and those in their middle adolescence did not make any comments regarding moral evaluation in choosing friends. 
Table 2

Tolerant Relationships by Age

\begin{tabular}{lllll}
\hline Tolerant Relationships & $\begin{array}{l}\text { Age } \\
9\end{array}$ & $\begin{array}{l}\text { Age } \\
10-12\end{array}$ & $\begin{array}{l}\text { Age } \\
13-15\end{array}$ & Total \\
& $\begin{array}{l}\text { years } \\
\text { old } \\
\text { old }\end{array}$ & $\begin{array}{l}\text { years } \\
\text { old }\end{array}$ & \\
& 0,00 & 66,67 & 33,33 & 100,00 \\
& 0,00 & 50,00 & 50,00 & 100,00 \\
\hline Living together as a family & & & & \\
There is no discrimination & 50,00 & 50,00 & 0,00 & 100,00 \\
Best Friendships Between groups & 16,67 & 83,33 & 0,00 & 100,00 \\
$\quad$ Minority group-majority group (Turkish-French) & 33,33 & 66,67 & 0,00 & 100,00 \\
$\quad$ Minority group-other minority groups (Turkish-Arabic /Chechen & 0,00 & 100,00 & 0,00 & 100,00 \\
$\quad$ Preferring own ingroup (Turkish-Turkish) & & & & \\
$\quad$ Moral evaluation in choosing friendship & & & & \\
Turkish-French Peer Relations & 27,78 & 61,11 & 11,11 & 100,00 \\
$\quad$ Relationship with respect & 0,00 & 80,00 & 20,00 & 100,00 \\
$\quad$ Relationship with playmate & 18,75 & 62,50 & 18,75 & 100,00 \\
$\quad$ Relationship with love & 17,50 & 66,25 & 16,25 & 100,00 \\
\hline SUM & $(17)$ & $(59)$ & $(20)$ & $(96)$ \\
\hline N (Documents) & $\% 17$ & $\% 61$ & $\% 20$ & $\% 100$ \\
\hline
\end{tabular}

\section{Discriminatory relationships}

Discriminatory Relationships consisted of two main codes as "Turkish-French Peer Relationships" and "Exclusion by Some French Teachers". "Turkish-French Peer Relations" consisted of the codes "Exclusion" and "Prejudice and Stereotypes". The code "exclusion" included two sub-codes as "Religious exclusion against minority group" and "Racial exclusion against minority group". "Prejudice and Stereotypes" consisted of five sub-codes as "Religious prejudice against minority group", "Religious prejudice against majority group", "Racial prejudice against minority group", "Racial prejudice against majority group" and "Racial stereotypes against the majority group" (Figure 2). 


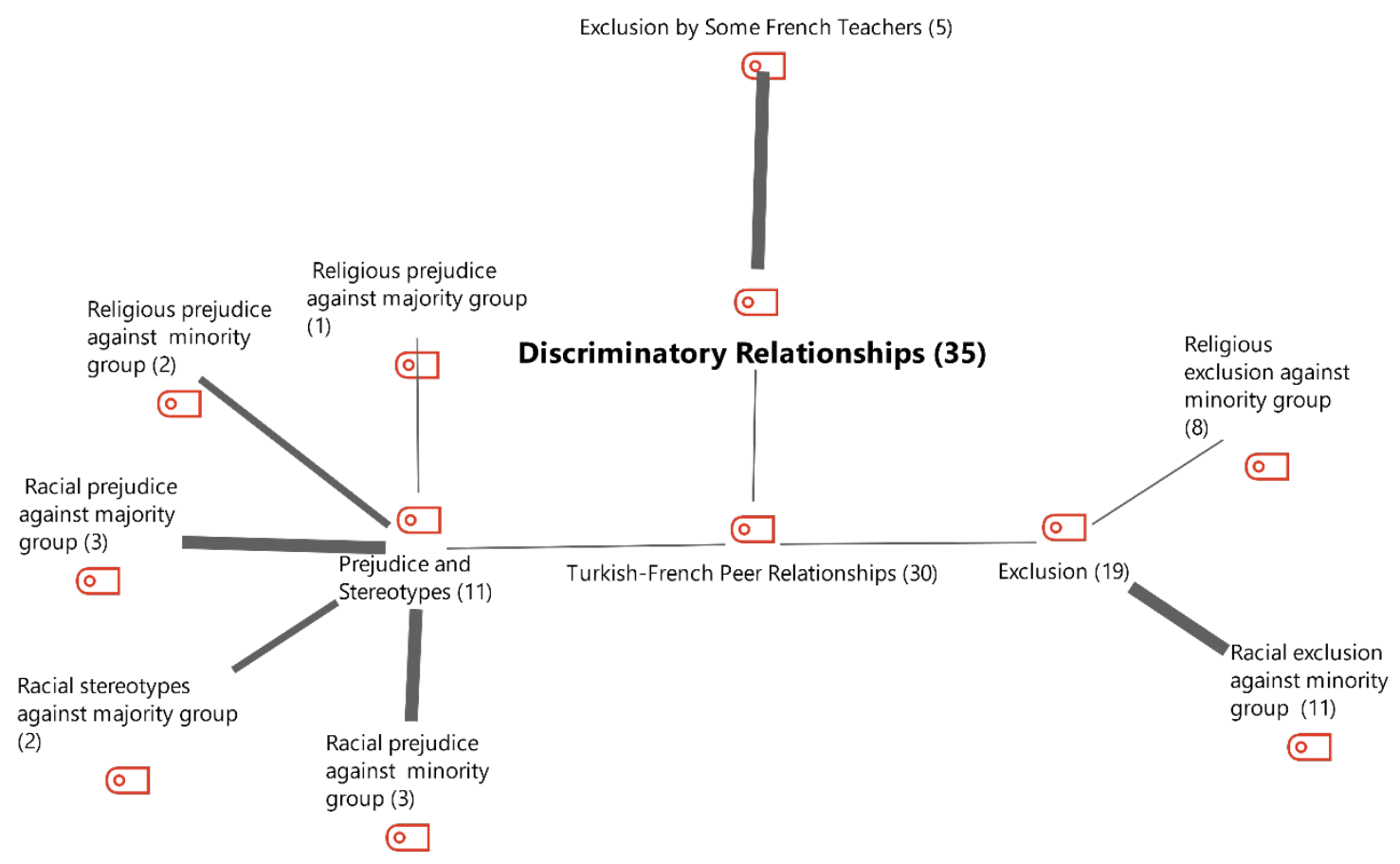

Figure 2. Discriminatory relationships code theory model

As seen in Table 3, the immigrant family children stated they were mostly exposed to religious exclusion by the native children. This exclusion was most often expressed by boys. According to the girls, the second most common type of exclusion among peers was racial exclusion. Visual indicators, signs and symbols related to religious or racial prejudice, discrimination and exclusion in some drawings of children were not one-sided but mutual between the majority and minority peers. The boys considered that there was no religious prejudice and racial stereotypes against the majority. The girls and boys considered that religious prejudice was in the same proportion against the minority. Although the research questions of this study were not directly related to this, some said discriminatory attitudes and behaviours were shown by French teachers rather than their peers. $60 \%$ of the boys and $40 \%$ of the girls expressed these attitudes against themselves in their drawings and interviews. 
Table 3

Discriminatory Relationships by Gender

\begin{tabular}{llll}
\hline Discriminatory Relationships & Boy & Girl & Total \\
\hline $\begin{array}{l}\text { Turkish-French Peer Relations } \\
\quad \text { Exclusion }\end{array}$ & & & \\
$\quad$ Religious exclusion against minority group & 87,50 & 12,50 & 100,00 \\
$\quad$ Racial exclusion against minority group & 36,36 & 63,64 & 100,00 \\
$\quad$ Prejudice and Stereotypes & & & \\
$\quad$ Religious prejudice against minority group & 50,00 & 50,00 & 100,00 \\
$\quad$ Religious prejudice against the majority group & 0,00 & 100,00 & 100,00 \\
$\quad$ Racial prejudice against minority group & 33,33 & 66,67 & 100,00 \\
$\quad$ Racial prejudice against majority group & 66,67 & 33,33 & 100,00 \\
$\quad$ Racial stereotypes against the majority group & 0,00 & 100,00 & 100,00 \\
Exclusion of Some French Teachers & 60,00 & 40,00 & 100,00 \\
\hline SUM & 51,43 & 48,57 & 100,00 \\
\hline N (Documents) & $(36)$ & $(60)$ & 96 \\
& $\% 37$ & $\% 62$ & $\% 100$ \\
\hline
\end{tabular}

As seen in Table 4, the 13-15-year-olds said they were mostly exposed to religious exclusion. The 10-12-year-olds also stated this exclusion, while the 9-year-olds did not mention the concept of religious exclusion. The 10-12-year-olds mostly expressed racial exclusion. These were respectively followed by the children in middle adolescence and the 9-year-olds. The 1315-year-olds said the exclusion shown against their minority group was mostly religion-based. They did not mention religious prejudice and stereotype. Both the 9-year-olds and 10-12-yearolds said minority group students had racial stereotypes about the majority group students. Likewise, both age groups expressed mutual racial prejudices between the groups. The 9-yearolds did not express religious prejudice and religious exclusion. Only one student stated she did not like French children because they are not Muslim. The 10-12-year-olds said they were exposed to religious prejudices by the native children. 
Table 4

Discriminatory Relationships by Age

\begin{tabular}{lllll}
\hline Discriminatory Relationships & $\begin{array}{l}\text { Age } \\
9\end{array}$ & $\begin{array}{l}\text { Age } \\
\text { years old } \\
\text { years old }\end{array}$ & $\begin{array}{l}\text { Age } \\
13-15 \\
\text { years old }\end{array}$ & Total \\
\hline $\begin{array}{l}\text { Turkish-French Peer Relations } \\
\quad \text { Exclusion }\end{array}$ & & & & \\
$\quad \begin{array}{l}\text { Religious exclusion against minority group } \\
\quad \text { Racial exclusion against minority group }\end{array}$ & 0,00 & 37,50 & 62,50 & 100,00 \\
$\quad \begin{array}{l}\text { Prejudice and Stereotypes } \\
\quad \text { Religious prejudice against minority group }\end{array}$ & 18,18 & 54,55 & 27,27 & 100,00 \\
$\quad$ Religious prejudice against the majority group & 0,00 & 100,00 & 0,00 & 100,00 \\
$\quad$ Racial prejudice against minority group & 100,00 & 0,00 & 0,00 & 100,00 \\
$\quad$ Racial prejudice against majority group & 33,33 & 66,67 & 0,00 & 100,00 \\
$\quad$ Racial stereotypes against the majority group & 33,33 & 66,67 & 0,00 & 100,00 \\
Exclusion of Some French Teachers & 50,00 & 50,00 & 0,00 & 100,00 \\
SUM & 0,00 & 80,00 & 20,00 & 100,00 \\
\hline N (Documents) & 17,14 & 57,14 & 25,71 & 100,00 \\
\hline & 17 & 59 & 20 & 96 \\
& $(\% 17)$ & $(\% 61)$ & $(\% 20)$ & $(\% 100)$ \\
\hline
\end{tabular}

Discussion

\section{Tolerant Relationships by Gender-Age}

In this study, there were more tolerant relationships than discrimination (see and compare code theory models: (Figure 1 and Figure 2). There were 4 themes that were the most common in the context of tolerant relationships: Relationship with respect (18 codes), relationship with love (16 codes), living together as a family ( 9 codes), there is no discrimination ( 8 codes) (Figure $1)$.

The girls had more positive relationships with their peers than the boys. Some studies also reported that boys prefer more social distance (Verkuyten \& Kinket, 2000) and being friends with ethnically similar peers (Shih, 1998).

The children had positive friendships with their host peers at most at the ages of 10-12, followed respectively by 9 and 13-15 (this age group did not mention their best friendships). Compared to the 10-12-year-old girls, the 9-year-olds and 13-15-year-old boys had more distant relationships with their French peers. The most common theme in friendship relationships with 
French peers for the 9-year-old girls and the 10-12-year-old boys was "respect" (Figure 3). The 10-12-year-old girls preferred friendship based on "love" which requires closer and special relationships with their native peers. They also befriended other ethnic minorities. This is also the only age group that made moral assessments while choosing their friends. The 9-year-olds did not mention "together as a family" and "there is no discrimination." These were respectively mentioned by the 10-12-year-olds and the 13-15-year-olds. The 10-12-year-olds and 13-15year-olds stated "there is no discrimination" in the same rate.

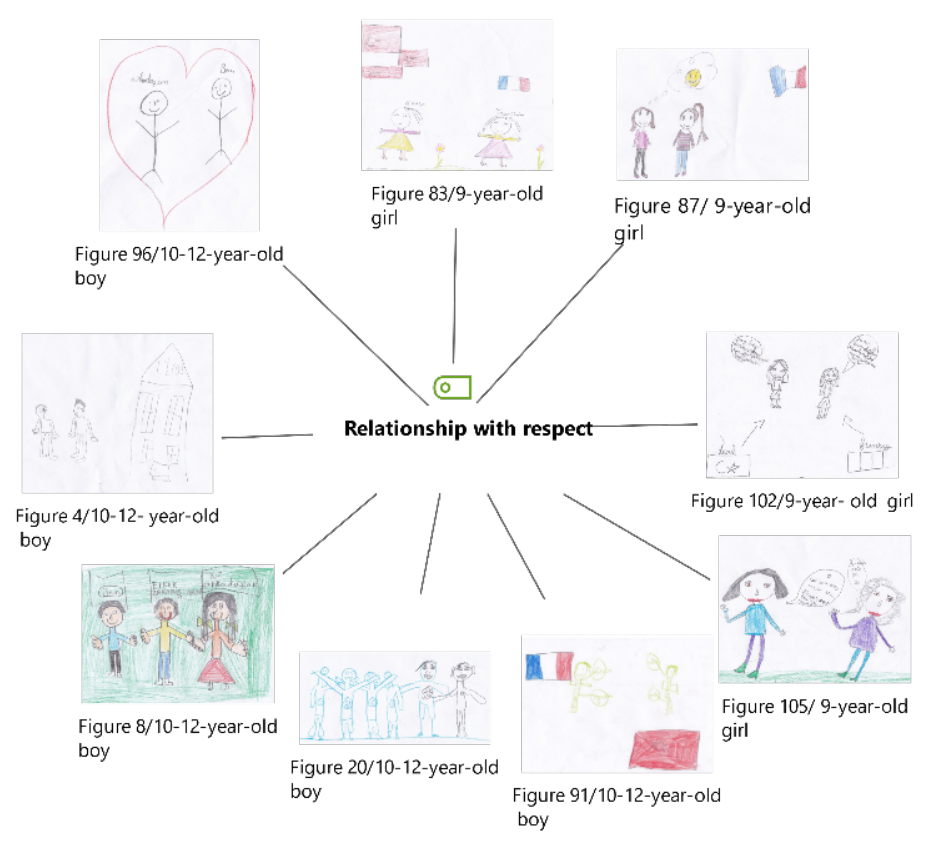

Figure 3. Relationship with respect single-code model for 9-year-old girls and 10-12-year-old boys

Each age group communicated with both their ethnic groups and other ethnic groups and native children. This study, therefore, did not correspond with the studies which showed immigrant children preferred their own co-ethnic friendships from pre-school (Finkelstein \& Haskins, 1983; Fishbein \& Imai, 1993; Leman et al., 2013) to childhood (Boulton, 1996; Leman \& Lam, 2008; Verkuyten \& Kinket, 2000) and from adolescence to youth (Brüß, 2005; Phinney et al., 1997) rather than inter-group friendships.

One may say the age group which was the most integrated with the host country was the 10-12year-olds, especially the girls. The most common theme in the 10-12-year-old girls was 
"relationship with love" (Figure 4). The only age group that made moral assessments in choosing friends was the 10-12-year-olds.

In the drawings of this age group, there was no distance between children, they were clearly in communication. Hands held, faces smiling, hearts, flowers, smileys, rainbows, heart-shaped Turkish and French flags. In the picture of a 12-year-old girl, there were two friends with French and Turkish flags on their skirts. French: "How are you, are you okay? You know I miss you so much?" Turk: "I'm fine, how are you? I missed you, too." French: "I am very happy to see you.” Turk: "Me, too". French: "I love you very much." Turk: "Me, too..."

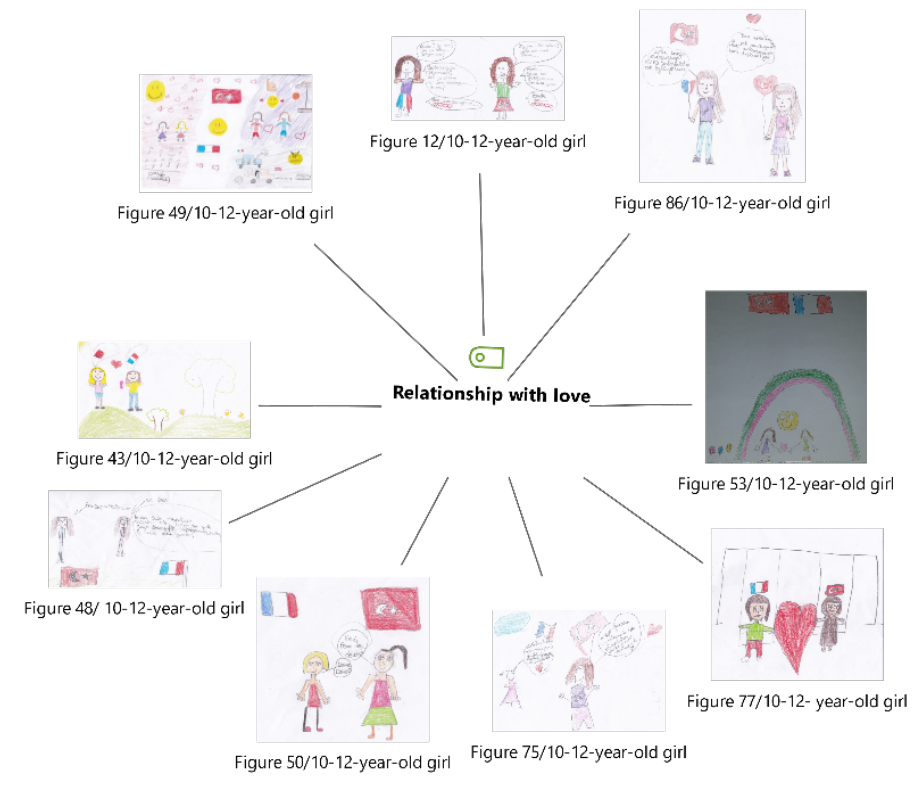

Figure 4. Relationship with love single-code model for 10-12- year-old girls

These results were similar to studies which reported that immigrants who feel more connected to the host country show less intra-group bias (Nier et al., 2001; Pfeifer et al., 2007) and those with a strong national identity may have more native friends (Agirdag, Van Houtte, \& Van Avermaet, 2011; Leszczensky, 2013; Munniksma et al., 2015; Sabatier, 2008).The best friends of the age group of 10-12 were respectively other minority groups, own ethnic groups and native children.

10-year-old girl: "I don't like my French classmate,. Because they want to have a fight and swear." 10-year-old girl: "There are good people from both Turks and the French. However, there are also bad people." Accordingly, the 10-12 age group ignored group norms in their friendship relationships and was influenced more by the personality traits of their friends by 
moral reasoning, justice and empathy. This result supported the statements of previous studies about minority children (Hitti et al., 2017; Malti et al., 2011; McGlothlin \& Killen, 2005; Park \& Killen, 2010; Turner \& Brown, 2007; Verkuyten \& Thijs, 2002)

The 9-year-olds did not mention "living together as a family" and "there is no discrimination." However, this age group had positive relationships with both their ethnic group and other ethnic groups and their native peers. Their lack of expressing these concepts related to coexistence may be related to their levels of cognitive development. The concepts "living together as a family" and "there is no discrimination" were said firstly by the 10-12-year-olds and then by the 13-15-year-olds. The 10-12- and 13-15-year-olds stated "there is no discrimination" in the same rate. This concept was the most common theme in the 13-15-year-old girls (Figure 5). In the drawings with the themes "living together as a family" and "there is no discrimination", there was no distance between children. There were children dressed in different colours and shapes. They were playing, smiling together holding hands in playgrounds and classrooms. There were hearts, flowers, rainbows, combinations of flags (Turkey, France, Switzerland, Algeria, Tunisia, Morocco). One may state that the children were integrated into French culture at different rates. The findings supported the view of multiculturalism that one's positive feelings about own group contribute to their positive emotions towards other groups (Lambert, Mermigis, \& Taylor, 1986; Phinney et al., 1997).

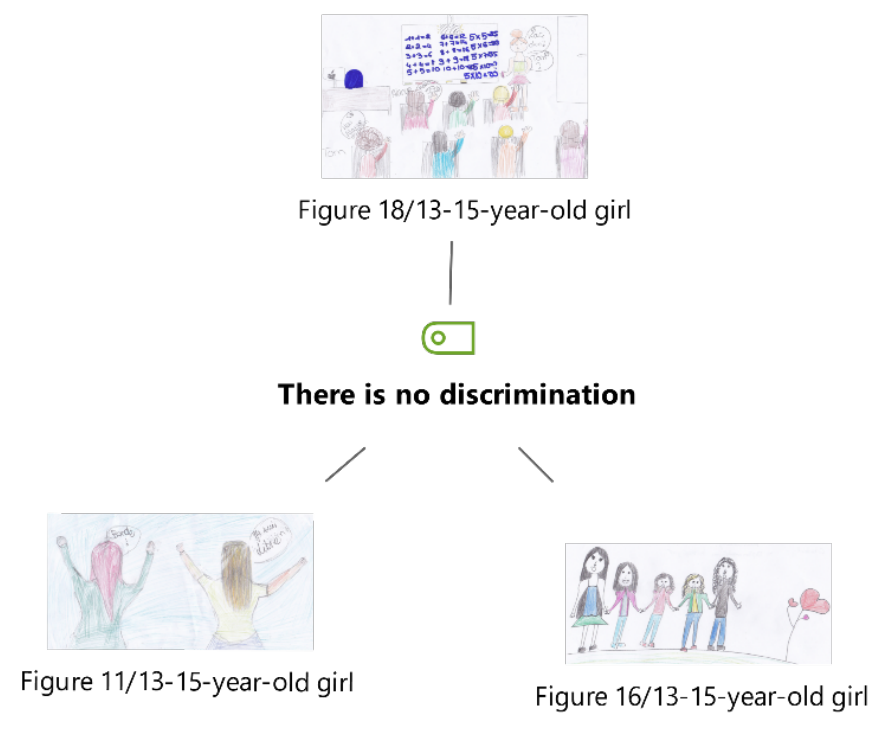

Figure 5. There is no discrimination single-code model for 13-15-year-old girls 


\section{Discriminatory Relationships by Gender-Age}

There were 3 themes that were the most common in the context of discriminatory relationships: racial exclusions against minority groups (11 codes), religious exclusions against minority groups ( 8 codes), exclusion by some French teachers (5 codes) (Figure 2). Although the research questions of this study were not directly related to this, some students said discriminatory attitudes and behaviours were shown by French teachers rather than their peers. $60 \%$ of the boys and $40 \%$ of the girls expressed these attitudes against themselves in their drawings and interviews.

The boys expressed the discriminatory attitudes and behaviours of their native peers more than the girls did. This may be due to the fact that girls prefer to belong to very small groups based on interests and interpersonal attraction, while boys are more attentive in competitive activities based on group identities (Schofield, 1981). The perception of racial exclusion was $18.18 \%$ in the 9 -year-olds, $54.55 \%$ in the 10 -12-year-olds. There was a decrease in this perception with a rate of $27.27 \%$ at the ages of $13-15$. This theme is the most common theme in discriminatory relationships for girls aged 10-12 (see Figure 6). Secondly, they stated that they were exposed to religious exclusion. This age group said they were mostly exposed to both religious and racial exclusion by French teachers rather than their French peers.

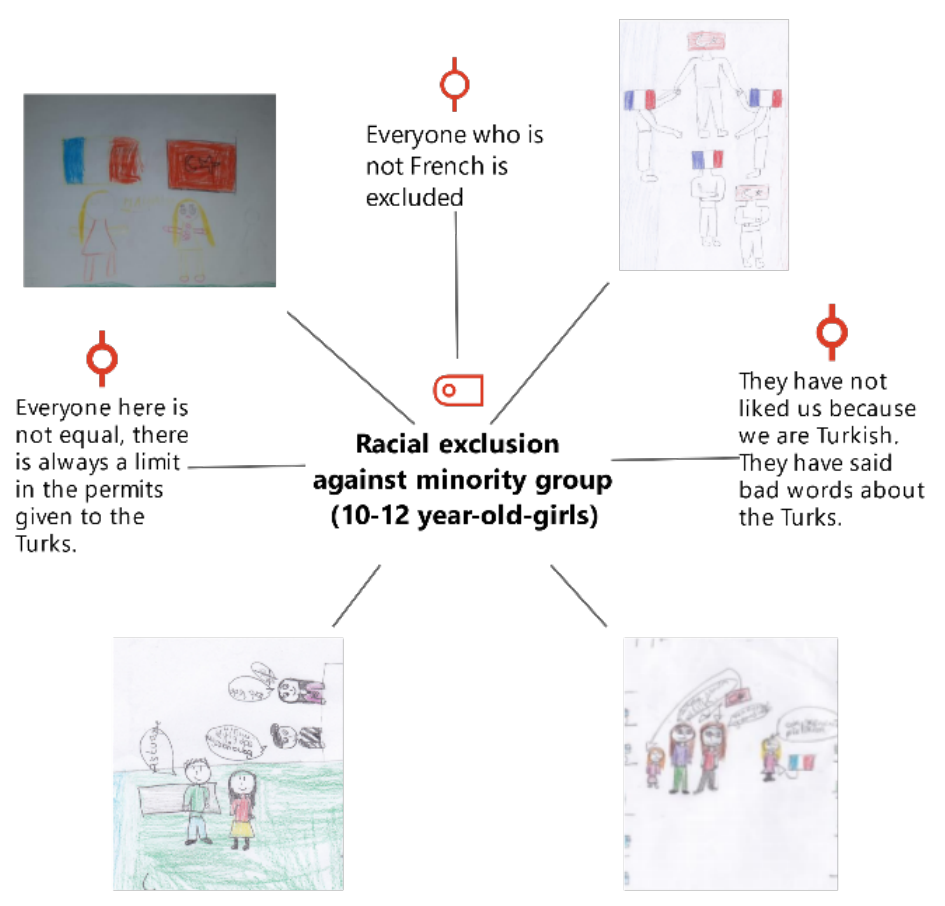

Figure 6. Racial exclusion against minority group single-code model for 10-12-year-old//7/ 
The perception of religious exclusion was not expressed by the 9-year-olds (but they were aware of religious differences), while the rates of stating this issue were $37.50 \%$ in the $10-12$-yearolds and $62.50 \%$ in the 13-15-year-olds. The perception of religious exclusion was the most common theme for the boys at the ages of 13-15 (Figure 7). The second thing they expressed was racial exclusion. This age group also stated that they were excluded by French teachers.

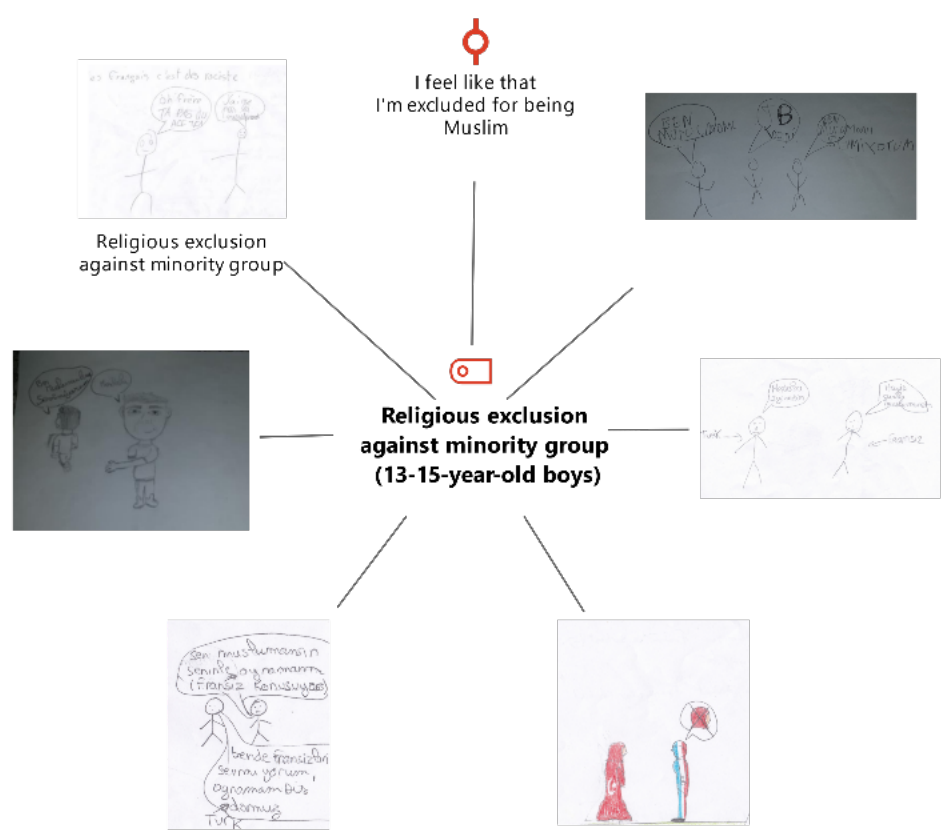

Figure 7. Religious exclusion against minority group single-code model for 13-15-year-old boy

There was an increase in the perceived racial/ethnic exclusion from 9 years to 10-12 years of age, but in the 13-15 age group, there was a decrease. The children's paintings showed an increase in racial/ethnic prejudice and exclusion attitudes and behaviours in children of both minority and majority groups, from 9 to 10 years of age. On the contrary, in the pictures of the children aged 13-15 years, there was a mutual decrease in the attitudes and behaviours of racial/ethnic prejudice and exclusion. Considering research that found a positive correlation between perceived discrimination and ethnic discovery (Pahl \& Way, 2006; Romero \& Roberts, 1998), in terms of children aged 9-12 years and 10-12 years, this results was similar to those of studies reporting that ethnic awareness increases with age (Clark \& Clark, 1950; Murphy \& Laugharne, 2013; Patterson \& Bigler, 2006), and children aged 7-8 understand that minority ethnic groups are associated with different stereotypes (Davis et al., 2007; Lam \& Leman, 2003). 
At 13-15 years of age, there is a decrease in mutual discrimination attitudes and behaviours (minority-majority), as well as the perception of racial/ethnic exclusion by immigrant children. Despite the increase in group normativity with age (Abrams, Rutland, \& Cameron, 2003), friendship choices at the age of 13 may focus on intergroup dynamics (Leman et al., 2013). In a study conducted with the 13-15 and 16-18 age groups, ethnic identity increased with age, and positive attitudes were predicted within the group. These attitudes positively contributed to nongroup attitudes (Phinney et al., 1997).

The majority of the students who stated that they were exposed to racial exclusion by their host peers stated that not all French children excluded Turks, and only some French children did so. Additionally, some Turkish children in the interviews stated the following: "If they (the French) exclude me, I exclude them, too. If they treat me well, I'm already playing with them. Some of my French friends are very good, we play with them all the time." These expressions support the results of a study (Nesdale \& Brown, 2004) which argued that children exposed to discrimination and feeling the perception of exclusion are at risk of exhibiting prejudiced behaviours and maintaining a negative attitude. Reitz et al. (2015) found immigrant youth could look beyond the perception of discrimination if they have quality in bilateral friendship relationships, and while personal ethnic discrimination is a consequence, a low number of peers is not preferential. These results were similar to the results of studies that found that minority children often show less intra-group bias than majority children (Griffiths \& Nesdale, 2006; Leman \& Lam, 2008; Phinney et al., 1997; Vaughan, 1978; Verkuyten, 2007).

In this study, religious prejudice and exclusion attitudes and behaviours increased as the ages increased in children's drawings. The number of the children who perceived religious exclusion also increased with age based on their statements in the interviews. Mostly, considering the positive correlation between perceived discrimination and ethnic discovery (Pahl \& Way, 2006; Romero \& Roberts, 1998), the results of this study were similar to those of van der Straten Waillet and Roskam (2012b). In another study by Roskam, religious discrimination was frequently seen in childhood but decreased in pre-adolescence and adolescence (Van der Straten Waillet \& Roskam, 2012b).

In the pictures with the theme of religious exclusion, there was a distance between Turkish and French children, and there were no indicators, signs or symbols indicating positive communication. The ones who communicated, greeted and offered to play together were 
Muslim children. However, they did not receive positive responses to these offers. In a picture of a 13-year-old student, Muslim child: "Hello." French child: "I don't like Muslims." (turning his back, he leaves). This student said in the interviews: "I like to live with other cultures in Strasbourg. I have little love for my French friends. Muslims here are mostly excluded by the French. It may be stated that religion is not an important factor for Muslim children in choosing friendships, but because they are excluded by some French friends, they mostly be friend Muslims. These results supported those of the studies showing that Christian and non-religious children have negative feelings towards Muslims and even perceive them as threats and are reluctant to befriend them (Leszczensky \& Pink, 2016; Velasco González et al., 2008; Verkuyten \& Thijs, 2010).

In this sample, some students stated that discriminatory attitudes and behaviours were shown by some French teachers rather than their peers. A boy aged 12: "Some French teachers discriminate against Muslims and exclude them. For example, they do not tell the history of Muslims in history classes. One time I asked my history teacher: 'Why are we learning only Christians and Jews and other religions? Do you ever not talk about Muslims?' I said. He said: "There are not just Muslims." In the picture of a 13-year-old girl in a math class, each student was painted with different colours and names that reflect ethnic and religious differences were written. This student spoke about her drawing in the interview: "I'm happy to live in Strasbourg. I love my French friends and I don't feel excluded. I have friends from various races and religions in the classroom. This is why I painted everyone in different colours. Our maths teacher equally treats Elanur who is Turkish and Tom who is French. He gives the right of speech to both." Supporting these statements, in a study conducted with children aged 6-14, the fact that teachers had a pro-diversity belief ensured that students had low levels of intentions of social exclusion regarding disadvantaged children. Conversely, if teachers do not have prodiversity beliefs, students may have more social exclusion tendencies in their friendship relationships. Teachers' perception of the differences in their classrooms to be valuable may encourage students to interact with their peers on the basis of individual differences and reduce their inter-group bias (Grütter \& Meyer, 2014).

\section{Limitation and Future Research Directions}

Limitations of this study warrant attention. Firstly, since the study was cross-sectional, it could not provide precise information about the causal aspects of the relationships between variables. 
As friendship relationships are dynamic processes that are affected by many factors and may change over time, to identify the causal aspects of relationships, there is a need for qualitative and longitudinal international studies. The second limitation of this study was that it was conducted in a unilateral manner (only Muslim children). To identify the models of friendship between immigrant and native children, according to a dynamic inter-group perspective (Brown \& Zagefka, 2011), both groups should be involved in potential formation of friendships. The majority of the comparative studies in the literature are quantitative. Future research could be carried out in larger samples, using an intergroup and mixed research design. Thirdly, in terms of examining only the 9-15 years of age, our research was limited to this age group. There are different results at earlier and later ages. Fourth of all, peer relationships were analysed in terms of age and gender by considering only the context of school. It was aimed to obtain information about the racial/ethnic and religious composition of the classes with an open-ended question, but the effect of the class composition could not be included in the study because the students could not provide enough information. In future research, the racial/ethnic and religious composition of the school and class (Kistner, Metzler, Gatlin, \& Risi, 1993; Pettigrew \& Tropp, 2006; Van der Straten Waillet \& Roskam, 2012b), parental ethnic and religious socialisation (Aronowitz, 1992; Sabatier, 2008; Spiegler, Güngör, \& Leyendecker, 2016) and neighbourhood composition (Mouw \& Entwisle, 2006) should be examined. Moreover, these secondgeneration culturing processes and their interrelationships are limited to the children of MuslimTurkish families born in Strasbourg. Relationships between immigrant and native children may be different in terms of immigrant children's racial/ethnic, national and religious identity and the country they immigrate to. To determine the extent of generalisability of other immigration contexts, it is necessary to reproduce the samples on the international level.

\section{Conclusion}

This study examined friendship relationships between 9-15-year-old Muslim-Turkish children and their French peers. It tried to examine whether there were differences in terms of gender and age in these relationships. As a result of systematic inductive analysis of children's drawings and semi-structured interviews, two main themes emerged as tolerant and discriminatory friendship relationships.

In comparison to the boys, the girls made more friends from among their French peers. Friendships with native peers increased from the age of 9 to 10-12. However, this rate decreased 
at the age of 13-15 years. Compared to the girls, the boys more frequently expressed that they were exposed to discriminatory attitudes and behaviours by their native friends.

In our study, the 9-year-old children were aware of racial/ethnic differences. However, they seemed to be unaware of religious differences (only one child mentioned religious differences). There was an increase from the age of 9 to 10-12 in terms of perceived racial/ethnic exclusion. This perception decreased in the age group of 13-15. There was a continuous increase in perceived religious exclusion with increasing age.

In this sample, the most frequent in-group and inter-group communication was in the 10-12year-olds. The fact that intercultural education programs consider the readiness level of this age group could positively affect inter-group friendships. These positive effects could be lasting on attitudes in youth and adulthood. Furthermore, considering that the real judgments of children's friendship potentials are influenced by the similarities in personality traits, interests and activities of their peers rather than group norms, intercultural education, ethics, democracy and citizenship, and intercultural religious education curriculums should focus on intercultural similarities rather than differences.

\section{Acknowledgement}

This study received no specific grant from any funding agency in the public, commercial, or not-for-profit sectors. I would like to thank Dr. M. Fevzi Hamurcu, Strasbourg Religious Affairs Attaché, for contributing to the research. Additionally, I would like to thank the teachers working at the Strasbourg Yunus Emre Mosque in the autumn semester of the academic year of 2017-2018.

\section{Statements on ethics and conflict of interest}

This research titled "Friendship Relationships between Turkish-French Children and Their French Peers" was approved by Hacı Bektaş Veli University Ethics Committee with the number 08 meeting dated 12.03.2020. Ethical issues were considered throughout the study. There is no conflict of interest in this study. 


\section{References}

Aboud, F. E. (1993). The developmental psychology of racial prejudice. Transcultural $\begin{array}{llll}\text { Psychiatric Research 229-242. } & \text { Review, }\end{array}$ https://doi.org/10.1177/136346159303000303

Aboud, F. E., Mendelson, M. J., \& Purdy, K. T. (2003). Cross-race peer relations and friendship quality. International Journal of Behavioral Development, 27(2), 165-173. https://doi.org/10.1080/01650250244000164

Abraham, A. (1990). The projection of the inner group in drawing. Group Analysis, 23, 391402.

Abrams, D., Rutland, A., \& Cameron, L. (2003). The Development of Subjective Group Dynamics: Children's Judgments of Normative and Deviant In-Group and Out-Group Individuals. Child Development, 74(6), 1840-1856. https://doi.org/10.1046/j.14678624.2003.00641.x

Agirdag, O., Van Houtte, M., \& Van Avermaet, P. (2011). Ethnic school context and the national and sub-national identifications of pupils. Ethnic and Racial Studies, 34(2), 357-378. https://doi.org/10.1080/01419870.2010.510198

Alba, R. (1999). Immigration and the American Realities of Assimilation and Multiculturalism. Sociological Forum, 14(1), 3-25. https://doi.org/10.1023/A:1021632626811

Alba, R. (2005). Bright vs. blurred boundaries: Second-generation assimilation and exclusion in France, Germany, and the United States. Ethnic and Racial Studies, 28(1), 20-49. https://doi.org/10.1080/0141987042000280003

Aronowitz, M. (1992). Adjustment of Immigrant Children as a Function of Parental Attitudes to Change. International Migration Review, 26(1), 89. https://doi.org/10.2307/2546938 
Berry, J. W., Kim, U., Power, S., Young, M., \& Bujaki, M. (1989). Acculturation Attitudes in Plural Societies. Applied Psychology, 38(2), 185-206. https://doi.org/10.1111/j.14640597.1989.tb01208.x

Bigler, R. S., \& Liben, L. S. (1993). A cognitive-developmental approach to racial stereotyping and reconstructive memory in Euro-American children. Child Development, 64(5), 1507. https://doi.org/10.2307/1131549

Bigler, R. S., \& Liben, L. S. (2007). Developmental Intergroup Theory: Explaining and Reducing Children's Social Stereotyping and Prejudice. Current Directions in Psychological Science, 16(3), 162-166. https://doi.org/10.1111/j.14678721.2007.00496.x

Boulton, M. J. (1996). Partner Preferences of British Asian and White Girls and Boys on the Middle School Playground: Do They Vary As a Function of Activity? Journal of Research in Childhood Education, 11(1), 25-34. https://doi.org/10.1080/02568549609594693

Bourhis, R. Y., Moise, L. C., Perreault, S., \& Senecal, S. (1997). Towards an Interactive Acculturation Model: A Social Psychological Approach. International Journal of Psychology, 32(6), 369-386. https://doi.org/10.1080/002075997400629

Brechwald, W. A., \& Prinstein, M. J. (2011). Beyond Homophily: A Decade of Advances in Understanding Peer Influence Processes. Journal of Research on Adolescence, 21(1), 166-179. https://doi.org/10.1111/j.1532-7795.2010.00721.x

Brown, R., \& Zagefka, H. (2011). The Dynamics of Acculturation. Advances in Experimental Social Psychology, 44, 129-184. https://doi.org/10.1016/B978-0-12-385522-0.00003-2

Brüß, J. (2005). Proud but isolated? Effects of in-group favouritism and acculturation preferences on inter-ethnic attitudes and contact between German, Turkish and resettler adolescents. Journal of Ethnic and Migration Studies, 31(1), 3-27. https://doi.org/10.1080/1369183042000305663

Clark, K. B., \& Clark, M. P. (1950). Emotional Factors in Racial Identification and Preference in Negro Children. The Journal of Negro Education, 19(3), 341-350. https://doi.org/10.2307/2966491 
Davey, A. G., \& Mullin, P. N. (1982). Inter-ethnic Friendship in British Primary Schools. Educational Research, 24(2), 83-92. https://doi.org/10.1080/0013188820240201

Davis, S. C., Leman, P. J., \& Barrett, M. (2007). Children's implicit and explicit ethnic group attitudes, ethnic group identification, and self-esteem. International Journal of Behavioral Development, 31(5), 514-525. https://doi.org/10.1177/0165025407081461

Enesco, I., Navarro, A., Paradela, I., \& Guerrero, S. (2005). Stereotypes and beliefs about different ethnic groups in Spain. A study with Spanish and Latin American children living in Madrid. Journal of Applied Developmental Psychology, 26(6), 638-659. https://doi.org/10.1016/j.appdev.2005.08.009

Feddes, A. R., Noack, P., \& Rutland, A. (2009). Direct and Extended Friendship Effects on Minority and Majority Children's Interethnic Attitudes: A Longitudinal Study: Direct and Extended Friendship Effects. Child Development, 80(2), 377-390. https://doi.org/10.1111/j.1467-8624.2009.01266.x

Finkelstein, N. W., \& Haskins, R. (1983). Kindergarten Children Prefer Same-Color Peers. Child Development, 54(2), 502-508. https://doi.org/10.2307/1129712

Fishbein, H. D., \& Imai, S. (1993). Preschoolers select playmates on the basis of gender and race. Journal of Applied Developmental Psychology, 14(3), 303-316. https://doi.org/10.1016/0193-3973(93)90012-k

Flanagan, C. A., Syvertsen, A. K., Gill, S., Gallay, L. S., \& Cumsille, P. (2009). Ethnic Awareness, Prejudice, and Civic Commitments in Four Ethnic Groups of American Adolescents. Journal of Youth and Adolescence, 38(4), 500-518. https://doi.org/10.1007/s10964-009-9394-z

Foner, N., \& Alba, R. (2008). Immigrant religion in the U.S. and Western Europe: Bridge or barrier to inclusion? International Migration Review, 42(2), 360-392. https://doi.org/10.1111/j.1747-7379.2008.00128.x

Griffiths, J. A., \& Nesdale, D. (2006). In-group and out-group attitudes of ethnic majority and minority children. International Journal of Intercultural Relations, 30(6), 735-749. https://doi.org/10.1016/j.ijintrel.2006.05.001 
Grütter, J., \& Meyer, B. (2014). Intergroup friendship and children's intentions for social exclusion in integrative classrooms: The moderating role of teachers' diversity beliefs: Social exclusion in integrative classrooms. Journal of Applied Social Psychology, 44(7), 481-494. https://doi.org/10.1111/jasp.12240

Hallinan, M. T., \& Teixeira, R. A. (1987). Opportunities and constraints: Black-white differences in the formation of interracial friendships. Child Development, 58(5), 13581371. https://doi.org/10.2307/1130627

Hitti, A., Mulvey, K. L., \& Killen, M. (2017). Minority and majority children's evaluations of social exclusion in intergroup contexts. In N. J. Cabrera \& B. Leyendecker (Eds.), Handbook on positive development of minority children and youth (pp. 281-293). Cham: Springer International Publishing.

Jugert, P., Noack, P., \& Rutland, A. (2011). Friendship Preferences Among German and Turkish Preadolescents: Friendship Preferences. Child Development, 82(3), 812-829. https://doi.org/10.1111/j.1467-8624.2010.01528.x

Kao, G., \& Joyner, K. (2004). Do Race and Ethnicity Matter Among Friends? Activities among Interracial, Interethnic, and Intraethnic Adolescent Friends. The Sociological Quarterly, 45(3), 557-573. https://doi.org/10.1111/j.1533-8525.2004.tb02303.x

Kawabata, Y., \& Crick, N. R. (2008). The role of cross-racial/ethnic friendships in social adjustment. Developmental Psychology, 44(4), 1177-1183. https://doi.org/10.1037/0012-1649.44.4.1177

Killen, M. (2007). Children's social and moral reasoning about exclusion. Current Directions in Psychological Science, 16(1), 32-36. Retrieved from http://www.jstor.org/stable/20183154

Kistner, J., Metzler, A., Gatlin, D., \& Risi, S. (1993). Classroom racial proportions and children's peer relations: Race and gender effects. Journal of Educational Psychology, 85(3), 446-452. https://doi.org/10.1037/0022-0663.85.3.446

Kowalski, K. (2003). The emergence of ethnic and racial attitudes in preschool-aged children. The Journal of Social Psychology, 143(6), 677-690. https://doi.org/10.1080/00224540309600424 
LaFromboise, T., Coleman, H. L. K., \& Gerton, J. (1993). Psychological impact of biculturalism: Evidence and theory. Psychological Bulletin, 114(3), 395-412. https://doi.org/10.1037/0033-2909.114.3.395

Lam, V. L., \& Leman, P. J. (2003). The influence of gender and ethnicity on children's inferences about toy choice. Social Development, 12(2), 269-287. https://doi.org/10.1111/1467-9507.00233

Lambert, W. E., Mermigis, L., \& Taylor, D. M. (1986). Greek Canadians' attitudes toward own group and other Canadian ethnic groups: A test of the multiculturalism hypothesis. Canadian Journal of Behavioural Science / Revue Canadienne Des Sciences Du Comportement, 18(1), 35-51. https://doi.org/10.1037/h0079952

Leman, P. J., Ben-Hmeda, M., Cox, J., Loucas, C., Seltzer-Eade, S., \& Hine, B. (2013). Normativity and friendship choices among ethnic majority- and minority-group children. International Journal of Behavioral Development, 37(3), 202-210. https://doi.org/10.1177/0165025413477315

Leman, P. J., \& Lam, V. L. (2008). The influence of race and gender on children's conversations and playmate choices. Child Development, 79(5), 1329-1343. https://doi.org/10.1111/j.1467-8624.2008.01191.x

Leman, P. J., Macedo, A. P., Bluschke, A., Hudson, L., Rawling, C., \& Wright, H. (2011). The influence of gender and ethnicity on children's peer collaborations. British Journal of Developmental Psychology, 29(1), 131-137. https://doi.org/10.1348/026151010x526344

Leszczensky, L. (2013). Do national identification and interethnic friendships affect one another? A longitudinal test with adolescents of Turkish origin in Germany. Social Science Research, 42(3), 775-788. https://doi.org/10.1016/j.ssresearch.2012.12.019

Leszczensky, L., \& Pink, S. (2015). Ethnic segregation of friendship networks in school: Testing a rational-choice argument of differences in ethnic homophily between classroom- and grade-level networks. Social Networks, 42, 18-26. https://doi.org/10.1016/j.socnet.2015.02.002 
Leszczensky, L., \& Pink, S. (2016). Intra- and inter-group friendship choices of Christian, Muslim, and Non-religious youth in Germany. European Sociological Review, 72-83. https://doi.org/10.1093/esr/jcw049

Leszczensky, L., Stark, T. H., Flache, A., \& Munniksma, A. (2016). Disentangling the relation between young immigrants' host country identification and their friendships with natives. Social Networks, 44, 179-189. https://doi.org/10.1016/j.socnet.2015.08.001

Lopez, A. B., Huynh, V. W., \& Fuligni, A. J. (2011). A longitudinal study of religious identity and participation during adolescence. Child Development, 82(4), 1297-1309. https://doi.org/10.1111/j.1467-8624.2011.01609.x

Maliepaard, M., Lubbers, M., \& Gijsberts, M. (2010). Generational differences in ethnic and religious attachment and their interrelation. A study among Muslim minorities in the Netherlands. Ethnic and Racial Studies, 33(3), 451-472. https://doi.org/10.1080/01419870903318169

Malti, T., Killen, M., \& Gasser, L. (2011). Social Judgments and Emotion Attributions About Exclusion in Switzerland. Child Development, 697-711. https://doi.org/10.1111/j.14678624.2011.01705.x

McGlothlin, H., \& Killen, M. (2005). Children's perceptions of intergroup and intragroup similarity and the role of social experience. Journal of Applied Developmental Psychology, 26(6), 680-698. https://doi.org/10.1016/j.appdev.2005.08.008

McLaren, L. M. (2003). Anti-Immigrant Prejudice in Europe: Contact, Threat Perception, and Preferences for the Exclusion of Migrants. Social Forces, 81(3), 909-936. https://doi.org/10.1353/sof.2003.0038

Meeus, W. (2011). The Study of Adolescent Identity Formation 2000-2010: A Review of Longitudinal Research. Journal of Research on Adolescence, 21(1), 75-94. https://doi.org/10.1111/j.1532-7795.2010.00716.x

Mouw, T., \& Entwisle, B. (2006). Residential Segregation and Interracial Friendship in Schools. American Journal of Sociology, 112(2), 394-441. https://doi.org/10.1086/506415 
Munniksma, A., Verkuyten, M., Flache, A., Stark, T. H., \& Veenstra, R. (2015). Friendships and outgroup attitudes among ethnic minority youth: The mediating role of ethnic and host society identification. International Journal of Intercultural Relations, 44, 88-99. https://doi.org/10.1016/j.ijintrel.2014.12.002

Murphy, A., \& Laugharne, J. (2013). Children's perceptions of national identity in Wales. Education 3-13, 41(2), 188-201. https://doi.org/10.1080/03004279.2011.567196

Nesdale, D., \& Brown, K. (2004). Children's attitudes towards an atypical member of an ethnic in-group. International Journal of Behavioral Development, 28(4), 328-335. https://doi.org/10.1080/01650250444000018

Nesdale, D., Maass, A., Griffiths, J., \& Durkin, K. (2003). Effects of in-group and out-group ethnicity on children's attitudes towards members of the in-group and out-group. British Journal of Developmental Psychology, 21(2), 177-192. https://doi.org/10.1348/026151003765264039

Nier, J. A., Gaertner, S. L., Dovidio, J. F., Banker, B. S., Ward, C. M., \& Rust, M. C. (2001). Changing Interracial Evaluations and Behavior: The Effects of a Common Group Identity. Group Processes \& Intergroup Relations, 4(4), 299-316. https://doi.org/10.1177/1368430201004004001

Pahl, K., \& Way, N. (2006). Longitudinal Trajectories of Ethnic Identity Among Urban Black and Latino Adolescents. Child Development, 77(5), 1403-1415. https://doi.org/10.1111/j.1467-8624.2006.00943.x

Park, Y., \& Killen, M. (2010). When is peer rejection justifiable? Children's understanding across two cultures. Cognitive Development, 25(3), 290-301. https://doi.org/10.1016/j.cogdev.2009.10.004

Pascoe, E. A., \& Smart Richman, L. (2009). Perceived discrimination and health: A metaanalytic review. Psychological Bulletin, 135(4), 531-554. https://doi.org/10.1037/a0016059

Patterson, M. M., \& Bigler, R. S. (2006). Preschool Children's Attention to Environmental Messages About Groups: Social Categorization and the Origins of Intergroup Bias. Child Development, 77(4), 847-860. https://doi.org/10.1111/j.1467-8624.2006.00906.x 
Pettigrew, T. F., \& Tropp, L. R. (2006). A meta-analytic test of intergroup contact theory. Journal of Personality and Social Psychology, 90(5), 751-783. https://doi.org/10.1037/0022-3514.90.5.751

Pfeifer, J. H., Ruble, D. N., Bachman, M. A., Alvarez, J. M., Cameron, J. A., \& Fuligni, A. J. (2007). Social identities and intergroup bias in immigrant and nonimmigrant children. Developmental Psychology, 43(2), 496-507. https://doi.org/10.1037/00121649.43.2.496

Phinney, J. S. (1989). Stages of Ethnic Identity Development in Minority Group Adolescents. The Journal of Early Adolescence, 9(1-2), 34-49. https://doi.org/10.1177/0272431689091004

Phinney, J. S. (1990). Ethnic identity in adolescents and adults: Review of research. Psychological Bulletin, 108(3), 499-514. https://doi.org/10.1037/0033-2909.108.3.499

Phinney, J. S., Ferguson, D. L., \& Tate, J. D. (1997). Intergroup attitudes among ethnic minority adolescents: A causal model. Child Development, 68(5), 955-969. https://doi.org/10.2307/1132044

Portes, A., \& Zhou, M. (1993). The New Second Generation: Segmented Assimilation and its Variants. The ANNALS of the American Academy of Political and Social Science, 530(1), 74-96. https://doi.org/10.1177/0002716293530001006

Ramsey, P. G. (1991). The salience of race in young children growing up in an all-White community. Journal of Educational Psychology, 83(1), 28-34. https://doi.org/10.1037/0022-0663.83.1.28

Ramsey, P. G., \& Myers, L. C. (1990). Salience of race in young children's cognitive, affective, and behavioral responses to social environments. Journal of Applied Developmental Psychology, 11(1), 49-67. https://doi.org/10.1016/0193-3973(90)90031-E

Reitz, A. K., Asendorpf, J. B., \& Motti-Stefanidi, F. (2015). When do immigrant adolescents feel personally discriminated against? Longitudinal effects of peer preference. International Journal of Behavioral Development, 39(3), 197-209. https://doi.org/10.1177/0165025414567008 
Romero, A. J., \& Roberts, R. E. (1998). Perception of discrimination and ethnocultural variables in a diverse group of adolescents. Journal of Adolescence, 21(6), 641-656. https://doi.org/10.1006/jado.1998.0185

Rosenbloom, S. R., \& Way, N. (2004). Experiences of Discrimination among African American, Asian American, and Latino Adolescents in an Urban High School. Youth \& Society, 35(4), 420-451. https://doi.org/10.1177/0044118X03261479

Sabatier, C. (2008). Ethnic and national identity among second-generation immigrant adolescents in France: The role of social context and family. Journal of Adolescence, 31(2), 185-205. https://doi.org/10.1016/j.adolescence.2007.08.001

Schaafsma, J., Nezlek, J. B., Krejtz, I., \& Safron, M. (2010). Ethnocultural identification and naturally occurring interethnic social interactions: Muslim minorities in Europe. European Journal of Social Psychology, 40(6), 1010-1028. https://doi.org/10.1002/ejsp.699

Schofield, J. W. (1981). The development of children's friendships. In S. A. Asher \& J. M. Gottman (Eds.), Complimentary and conflicting identities: Images of inretaction in an interracial school (pp. 53-90). New York: Cambridge University Press.

Seul, J. R. (1999). 'Ours is the way of God': Religion, identity, and intergroup conflict. Journal of Peace Research, 36(5), 553-569. https://doi.org/10.1177/0022343399036005004

Shih, T. A. (1998). Finding the niche: Friendship formation of immigrant adolescents. Youth \& Society, 30(2), 209-240. https://doi.org/10.1177/0044118X98030002004

Smith, A., \& Schneider, B. H. (2000). The inter-ethnic friendships of adolescent students: A Canadian study. International Journal of Intercultural Relations, 24(2), 247-258. https://doi.org/10.1016/S0147-1767(99)00034-6

Smith, S., Maas, I., \& van Tubergen, F. (2014). Ethnic ingroup friendships in schools: Testing the by-product hypothesis in England, Germany, the Netherlands and Sweden. Social Networks, 39, 33-45. https://doi.org/10.1016/j.socnet.2014.04.003

Spiegler, O., Güngör, D., \& Leyendecker, B. (2016). Muslim Immigrant Parents' Social Status Moderates the Link Between Religious Parenting and Children's Identification with the 
Heritage and Host Culture. Journal of Cross-Cultural Psychology, 47(9), 1159-1177. https://doi.org/10.1177/0022022116665170

Stark, T. H., Flache, A., \& Veenstra, R. (2013). Generalization of Positive and Negative Attitudes Toward Individuals to Outgroup Attitudes. Personality and Social Psychology Bulletin, 39(5), 608-622. https://doi.org/10.1177/0146167213480890

Stevens, G. W. J. M., Pels, T. V. M., Vollebergh, W. A. M., \& Crijnen, A. A. M. (2004). Patterns of Psychological Acculturation in Adult and Adolescent Moroccan Immigrants Living in the Netherlands. Journal of Cross-Cultural Psychology, 35(6), 689-704. https://doi.org/10.1177/0022022104270111

Strabac, Z., \& Listhaug, O. (2008). Anti-Muslim prejudice in Europe: A multilevel analysis of survey data from 30 countries. Social Science Research, 37(1), 268-286. https://doi.org/10.1016/j.ssresearch.2007.02.004

Strauss, A. L., \& Corbin, J. M. (1990). Basics of qualitative research: Grounded theory procedures and techniques. Newbury Park: Sage Publications.

Szapocznik, J., \& Kurtines, W. M. (1993). Family psychology and cultural diversity: Opportunities for theory, research, and application. American Psychologist, 48(4), 400407. https://doi.org/10.1037/0003-066X.48.4.400

Ting-Toomey, S. (1981). Ethnic identity and close friendship in Chinese-American college students. International Journal of Intercultural Relations, 5(4), 383-406. https://doi.org/10.1016/0147-1767(81)90049-3

Turner, K. L., \& Brown, C. S. (2007). The Centrality of Gender and Ethnic Identities across Individuals and Contexts. Social Development, 16(4), 700-719. https://doi.org/10.1111/j.1467-9507.2007.00403.x

Van der Straten Waillet, N., \& Roskam, I. (2012a). Developmental and social determinants of religious social categorization. The Journal of Genetic Psychology, 173(2), 208-220. https://doi.org/10.1080/00221325.2011.600356 
Van der Straten Waillet, N., \& Roskam, I. (2012b). Religious discrimination in childhood and adolescence. Archive for the Psychology of Religion, 34(2), 215-242. https://doi.org/10.1163/15736121-12341240

Van Oudenhoven, J. P., Prins, K. S., \& Buunk, B. P. (1998). Attitudes of minority and majority members towards adaptation of immigrants. European Journal of Social Psychology, 28(6), 995-1013. https://doi.org/10.1002/(SICI)1099-0992(1998110)28:6<995::AIDEJSP908>3.0.CO;2-8

Vaughan, G. M. (1978). Social change and intergroup preferences in New Zealand. European Journal of Social Psychology, 8(3), 297-314. https://doi.org/10.1002/ejsp.2420080304

Velasco González, K., Verkuyten, M., Weesie, J., \& Poppe, E. (2008). Prejudice towards Muslims in the Netherlands: Testing integrated threat theory. British Journal of Social Psychology, 47(4), 667-685. https://doi.org/10.1348/014466608X284443

Verkuyten, M. (2007). Ethnic in-group favoritism among minority and majority groups: Testing the self-esteem hypothesis among preadolescents. Journal of Applied Social Psychology, 37(3), 486-500. https://doi.org/10.1111/j.1559-1816.2007.00170.x

Verkuyten, M., \& Kinket, B. (2000). Social distances in a multi ethnic society: The ethnic hierarchy among Dutch preadolescents. Social Psychology Quarterly, 63(1), 75. https://doi.org/10.2307/2695882

Verkuyten, M., \& Martinovic, B. (2012). Immigrants' National Identification: Meanings, Determinants, and Consequences: National Identification of Immigrants. Social Issues and Policy Review, 6(1), 82-112. https://doi.org/10.1111/j.1751-2409.2011.01036.x

Verkuyten, M., \& Thijs, J. (2002). Racist victimization among children in The Netherlands: The effect of ethnic group and school. Ethnic and Racial Studies, 25(2), 310-331. https://doi.org/10.1080/01419870120109502

Verkuyten, M., \& Thijs, J. (2010). Religious group relations among Christian, Muslim and Nonreligious early adolescents in the Netherlands. The Journal of Early Adolescence, 30(1), 27-49. https://doi.org/10.1177/0272431609342984 
Verkuyten, M., Thijs, J., \& Sierksma, J. (2014). Majority Children's Evaluation of Acculturation Preferences of Immigrant and Emigrant Peers. Child Development, 85(1), 176-191. https://doi.org/10.1111/cdev.12111

Verkuyten, M., Thijs, J., \& Stevens, G. (2012). Multiple identities and religious transmission: A study among Moroccan-Dutch Muslim adolescents and their parents. Child Development, 83(5), 1577-1590. https://doi.org/10.1111/j.1467-8624.2012.01794.x

Vermeij, L., van Duijn, M. A. J., \& Baerveldt, C. (2009). Ethnic segregation in context: Social discrimination among native Dutch pupils and their ethnic minority classmates. Social Networks, 31(4), 230-239. https://doi.org/10.1016/j.socnet.2009.06.002

Vervoort, M. H. M., Scholte, R. H. J., \& Scheepers, P. L. H. (2011). Ethnic composition of school classes, majority-minority friendships, and adolescents' intergroup attitudes in the Netherlands. Journal of Adolescence, 34(2), 257-267. https://doi.org/10.1016/j.adolescence.2010.05.005

Windzio, M., \& Wingens, M. (2014). Religion, friendship networks and home visits of immigrant and native children. Acta Sociologica, 57(1), 59-75. https://doi.org/10.1177/0001699313481226

Wong, C. A., Eccles, J. S., \& Sameroff, A. (2003). The Influence of Ethnic Discrimination and Ethnic Identification on African American adolescents' School and Socioemotional Adjustment. Journal of Personality, 71(6), 1197-1232. https://doi.org/10.1111/14676494.7106012

Yıldırım, A., \& Şimşek, H. (2016). Sosyal bilimlere nitel araştırma yöntemleri (10. basım). Ankara: Seçkin yayıncılık.

Zagefka, H., Tip, L. K., González, R., Brown, R., \& Cinnirella, M. (2012). Predictors of majority members' acculturation preferences: Experimental evidence. Journal of Experimental Social Psychology, 48(3), 654-659. https://doi.org/10.1016/j.jesp.2011.12.006 